\title{
Web platform for aeroponic culture systematization
}

\section{Plataforma web para la sistematización de cultivo aeropónico}

PAREDES-XOCHIHUA, Maria Petra†*, MORALES-ZAMORA, Vianney, CUAMATZI-MUÑOZ, Martín and LEAL-CASIQUE, José de la Luz

Instituto Tecnológico Superior de San Martín Texmelucan, Camino a Barranca de Pesos S/N San Lucas Atoyatenco San Martín Texmelucan, Puebla. C.P. 74120

ID $1^{\text {st }}$ Author: Maria Petra, Paredes-Xochihua / ORC ID: 0000-0003-1753-2313, Researcher ID Thomson: S-6991-2018, CVU CONACYT ID: 298117

ID $1^{\text {st }}$ Coauthor: Vianney, Morales-Zamora / ORC ID: 0000-0002-1181-825X, Researcher ID Thomson: S-6627-2018, CVU CONACYT ID: 308547

ID $2^{\text {nd }}$ Coauthor: Martín, Cuamatzi-Muñoz / ORC ID: 0000-0002-9503-8161, arXiv Author ID: 3463457, CVU CONACYT ID: 265410

ID $3^{\text {rd }}$ Coauthor: José de la Luz, Leal-Casique / ORC ID: 0000-0002-5550-3364, PubMed Author ID: ABD-9336-2020, CVU CONACYT ID: 1094817

DOI: 10.35429/EJDRC.2020.10.6.22.26

Received March 28, 2020; Accepted June 30, 2020

\begin{abstract}
Today there is a tendency to automate almost everything around us because of the circumstances that arise in the world. So, the growing boom in online platform creation, they are allowing from managing until controlling the automation of information or processes of the different sectors: productive, agricultural, economic, productive, etc. The agricultural sector relies more on the implementation of such digital platforms. Therefore, this work presents a web platform that allows to systematize an aeroponic greenhouse to improve the quality of the processes in the production of them. It aims to record planting dates, monitor environmental variables, establish spray cycles depending on the type of crop, register crops and users, among other functionalities. Thus allowing the producer to have information whereever and whenever he wants or needs to consult for decision making.
\end{abstract}

\section{Aeroponics, Web platform, Crop monitoring}

\begin{abstract}
Resumen
Actualmente se tiene la tendencia de automatizar casi todo lo que nos rodea por las circunstancias que se presentan en el mundo. Por lo que, el creciente auge en la creación de plataformas en línea, están permitiendo desde la administración hasta el control de la automatización de información o procesos de los diferentes sectores: productivos, agrícolas, económicos, productivos, etc. El sector agrícola día a día confía más en la implementación de este tipo de plataformas digitales. Por lo que, en este trabajo se presenta una plataforma web que permite sistematizar un invernadero aeropónico para mejorar la calidad de los procesos en la producción de los mismos. Está tiene como objetivo registrar fechas de siembra, monitorizar variables ambientales, establecer ciclos de aspersión dependiendo del tipo de cultivo, registrar cultivos y usuarios, entre otras funcionalidades. Permitiendo así al productor tener información en cualquier lugar y hora en que desee o necesite consultar para la toma de decisiones.
\end{abstract}

Aeropónico, Plataforma web, Monitoreo de cultivos

Citation: PAREDES-XOCHIHUA, Maria Petra, MORALES-ZAMORA, Vianney, CUAMATZI-MUÑOZ, Martín and LEAL-CASIQUE, José de la Luz. Web platform for aeroponic culture systematization. ECORFAN Journal-Democratic Republic of Congo. 2020, 6-10: 22.26

\footnotetext{
* Correspondence to Author (email: petrypx@ hotmail.com)

$\dagger$ Researcher contributing first author.
} 


\section{Introduction}

Currently, the conviction for the use of digital platforms or web information systems has increased in all productive sectors: primary (agriculture, livestock, fishing), secondary (industry and construction) and tertiary (commerce, transport and tourism), among others.

According to the FAO (Food and Agriculture Organization of the United Nations, 2017) there is a strong growth in the automation of agricultural work taking into account technological evolution and the population expansion of the planet.

HSBC (2019), mentions that Agriculture 4.0 is the result of the evolution of e-agriculture in which data analysis, mobile communication and cloud services were introduced. It is about the fusion of the needs of the farmer with the most sophisticated advances in technology, in this way the potential of the information thrown by the field is used to change the way of production of food systems with the aim of solving three problems fundamental:

1. Global changes in production conditions

2. Population increase

3. Loss and waste. (HSBC, 2019)

FAO recognizes e-agriculture as a facilitator by improving information and communication processes. Hence, the importance of understanding and applying Information and Communication Technologies (ICT) in the agricultural field. The adoption of digital technologies in the agricultural sector has increased at a rapid rate, especially in the category of "precision agriculture". This methodology is developed based on programs and data to manage and optimize crop production. The application of this technology in agriculture aims to promote the development of capacities to renew the tasks of the field and its profitability (HSBC, 2019).

The aforementioned, allows setting the objective of developing a digital platform that systematizes some of the processes that are carried out in aeroponic crops in a greenhouse. The web platform allows for various functionalities, including the monitoring of variables that directly affect the evolution of the crop, optimizing care, among others that will be described in the development phase.

\section{Methodology}

For the development of any computer solution it is necessary to follow a software development methodology, as well as to know terms that are necessary to understand regarding aeroponic crops. So some of the employees are described below.

Aeroponics is the process of growing plants in an aerial or foggy environment without the use of soil. The word "aeroponics" comes from the Greek terms aero and ponos which mean air and work respectively. Aeroponic cultures differ from conventional hydroponic cultures and in vitro growth. (Agroislas, 2019)

Therefore, an aeroponic cycle harvesting system focuses on growing plants in a closed or semi-closed environment where nutrient sprays lift the nutrient solution and spray on the aerial roots that hang in the air. The supporting roots are constantly immersed in an oxygen-rich nutrient. (Agroislas, 2019)

Some authors use the word hydroponics to also refer to aeroponics. Due to the increase in the area destined for hydroponics, it has increased in recent years due to the importance it is taking due to the overpopulation that is occurring in the world and, consequently, the increase in the demand for agricultural products. This is why several countries around the world are adopting this method. Currently, the area of hydroponic greenhouses around the world covers an area of approximately 25,000 ha. (Gualotuña Simbaña, 2018).

Next, some basic concepts characteristic of an aeroponic greenhouse process will be mentioned:

- $\quad$ Sprinkler systems: Applying water to crops requires the use of sprinklers, sprayers, foggers, or other devices to create a fine mist of solution necessary to deliver nutrients to roots. (Garcia, 2020) 
- Solenoid Valve / Electrovalve: It is a valve designed to control the passage of a fluid through a conduit or pipe, they are made up of two different but complementary actuating parts: the valve body and a solenoid located inside the electric coil. When the coil is energized, a strong magnetic force is created in it that attracts a magnetic steel plunger that is located in the center of the coil, (Microbyte Ltda. 2019).

REST API: It is a set of functions or procedures used by computer programs to access the services of the operating system, software libraries, or other systems. Objects in REST are always manipulated from the URL. The URL is the unique identifier for each resource in that REST system. The URL makes it easy to access the information for modification or deletion, or to share with third parties. (Anonymous, 2016)

For the development of the platform, different software tools were used, some of these are mentioned: JSON (JavaScript Object Notation), Django Rest Framework, Rest Framework Token, Raspberry PI, among others.

\section{SCRUM software development methodology}

In order to structure, plan and control the development process in information systems. Several iterations were performed, some of these are described below:

Iteration 1- Database: Everything involved with the design of the Database was carried out (Analysis of information, realization of data dictionaries and class diagram).

The following requirements were defined: User registration, User update, Login, Logout, show user, crop registration, Activate crop / Start of harvest process, Spray cycle record, List of existing crops, List of process dates of cultivation, Monitoring record, Show monitoring by day, Generate averages for weeks and month of the process, Show detail of harvest process (monitoring - report), Activity history and Show information of the crop in harvest process, deactivate crop / conclude Harvest process, Database backup and Restore database.
The structure is designed for an easy integration of information, it was with the entities defined for this project are:

- CustomUser. The main function of this entity will be to store information such as username, password, role.

- InfoUser. Entity where personal information of users will be stored to better identify and personalize them within the software.

- History. Entity built in order to store activity (log) to identify the user responsible for each movement.

- RegisterCrop. Entity that will save initial information on the fruits that are harvested in the greenhouse.

- $\quad$ RegisterDate. Entity where the harvest start dates of the existing fruits will be registered within the software

- Sprinkling. Entity that will store the execution and waiting times of the irrigation cycle of the existing fruits

- MonitoringDay. Entity where the readings obtained in the environment circuit and the fruit in the harvest process will be saved.

- Token. Entity in charge of storing password information for user authentication.

Iteration 2 - Platform design: developed in Balsamiq Mockups. In figure 1, the sprinkling process is presented, in which the crop is placed, the sprinkling cycle and the waiting time are established. Figure 2 shows the monitoring design of some of the variables per day.

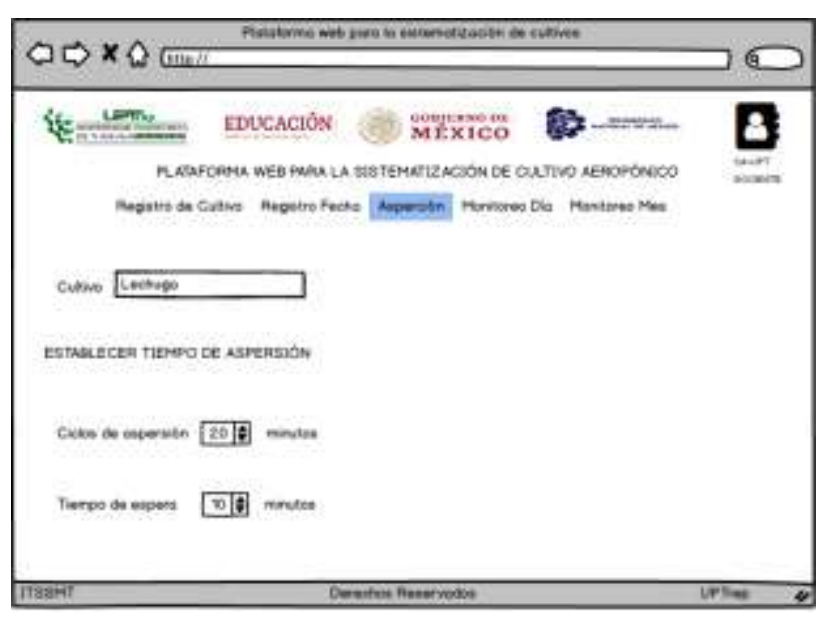

Figure 1 Sprinkling process

Source: Self Made 


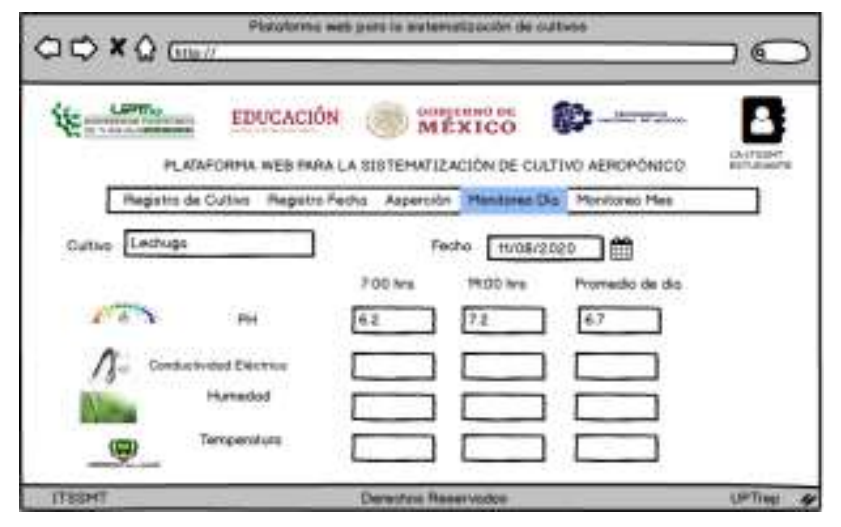

Figure 2 Variable monitoring Source: Self Made

\section{Iteration 3 Users Module}

In this iteration the requirements to be completed will be based on functions where the customuser and infouser models are involved, as well as the management and control of backups in the database. An example of the endpoint (see Figure 3) of the information that is required is shown. Taken from the documentation created for the API.

Figure 4 presents the function that was considered to show the information related to a user, that is, a display of the user micro profile. It will only work with the infouser entity.

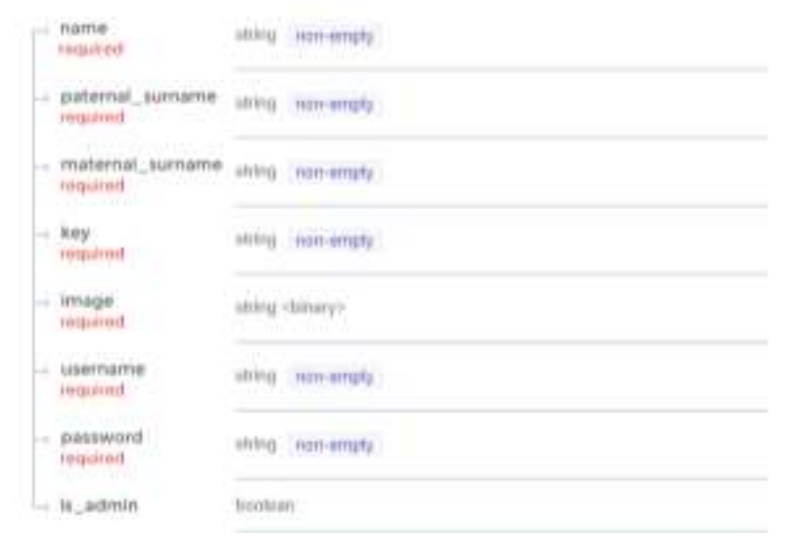

Figure 3 User register

Source: Self Made

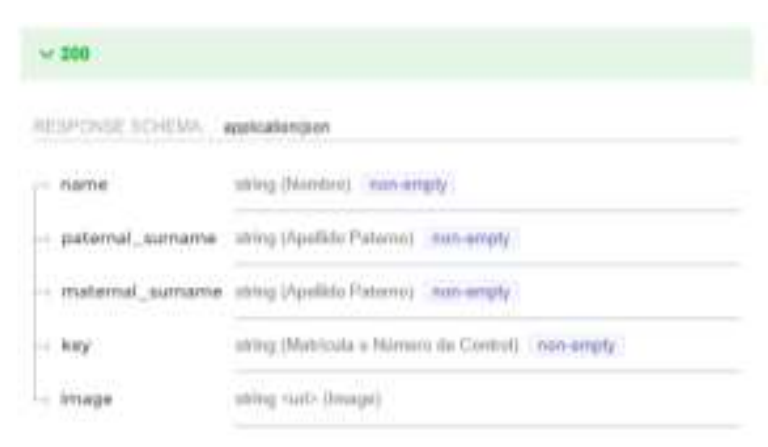

Figure 4 User information

Source: Self Made
This article only shows some of the parts of the process that were automated on the platform. One of the advantages of the platform is the fact that the relevant variables of the crop are monitored during the production time, as requested. Generating graphs that allow observing how the behavior of these variables varies in the crop and activating the sprinkling times.

\section{Results}

The results obtained with the web platform have been relevant given that in the face of the current problem where most of the activities that were done manually, it has been necessary to migrate in almost everything to the use of ICTs, for what this allows to give the appropriate follow-up to the crops in time and form, and thus avoid that people move to the site to carry out said activities, to do it in a regular way, so it allows to save economically, there is still the limiting given that it is available for certain crops, and the knowledge of different types of experts is needed, however, since each greenhouse has its dimensions and capacities.

\section{Acknowledgments}

To the General Directorate of the Higher Technological Institute of San Martín Texmelucan, for supporting collaborative work with other External Academic Bodies.

To the Rectory of the Polytechnic University of Tlaxcala Region Poniente, for allowing collaboration with other External Academic Bodies.

\section{Conclusions}

It is concluded that the web platform allows to automate the care of crops, improving the activity and the way to optimize the time invested in this activity by people.

Some variables were identified that are not considered in the monitoring and which could improve the quality of the crop. Likewise, some functionalities that the platform does not yet have are identified, for example, that it is possible to add as many variables as necessary, add crops, although for this, the experience of qualified personnel is needed. 


\section{References}

Agroislas (2019). ¿Qué es la aeroponia?. 2020, febrero, 21. Recuperado de: https://agroislas.com/blog/3420-aeroponia-esel-proceso-de-cultivar-plantas-en-un-entornoaereo-o-de-niebla-sin-hacer-uso-de-suelo-lapalabra-aeroponia-viene-de-losterminosgriegos-aero-y-ponos-que-significanrespectivamente-aire-y-trabajo

Anónimo (2016). Ebook - Introducción al mundo de las APIs. BBVA Bancomer. Recuperado de: https://bbvaopen4u.com/sites/default/files/eboo k/bbva-open4u-ebook-101-apis-espok.pdf

Aprende Ciencia y Tecnología. (2019). ¿Qué es el cultivo aeropónico o aeroponía?. 2020, abril, 20, de: Aprende Ciencia y Tecnología. Recuperado de: https://aprendecienciaytecnologia.com/2018/11/ 28/que-es-el-cultivo-

aeroponico/\#: :text=El\%20cultivo\%20aerop\%

C3\%B3nico\%20o\%20aeropon\%C3\%ADa\%20e s\%20el\%20proceso\%20mediante\%20el,un\%20 tipo $\% 20$ de $\% 20$ cultivo\%20hidrop\%C3\%B3nico

FAO. (2018). Conferencia Regional de La FAO para Europa. 2020, abril, 12. Recuperado de: http://www.fao.org/3/MW106ES/mw106es.pdf

Galván Rene. (2015). Qué es la Aeroponía. Agricultures - Red de especialistas en agricultura. 2020, abril, 18. Recuperado de: https://agriculturers.com/que-es-la-aeroponia/

García Mejía, E. E. (2020). Sistema web para la trazabilidad de clientes y la comercialización de plantas ornamentales (Tesis Doctoral, Instituto Tecnológico de Colima).

HSBC. (2019). Tecnología para la agricultura. 2020, febrero, 15, de Artículos y videos. Recuperado de: https://www.empresas.hsbc.com.mx/es$\mathrm{mx} / \mathrm{mx}$ /article/tecnologia-para-la-agricultura

INFOSOFT. (2018). Servicios. 2020, octubre,13, de: Nos especializamos en soluciones a medida. Recuperado de: https://www.infosoft.cl/service.php
Organización de las Naciones Unidas para la Alimentación y la Agricultura (FAO). (2017). El estado mundial de la agricultura y la alimentación. 2020, marzo, 25. Recuperado de: http://www.fao.org/3/a-I7658s.pdf

Microbyte Ltda. (2019). Cómo funciona una válvula solenoide. Revista Electro Industria Soluciones Tecnológicas para Minería, Energía e Industria. 2020, febrero, 15. Recuperado de: $\mathrm{http} / / / \mathrm{www} . \mathrm{emb} . \mathrm{cl} / \mathrm{electroindustria/articulo.mv}$ c? $\mathrm{xid}=3514 \&$ ni $=$ como-funciona-una-valvulasolenoide 